\title{
New Locality and Elevational Record of the Yellow-striped Glass Frog, Hyalinobatrachium vireovittatum (Starrett and Savage 1973) (Anura: Centrolenidae), from Coto Brus, Puntarenas, Costa Rica
}

\author{
Jorge Campos-Villalobos ${ }^{1}$, Gerald Pereira-Castillo ${ }^{3}$, Andrey Solís-Mora ${ }^{4}$, Víctor Serrano-Hernández ${ }^{2}$, \\ Henry Sandi-Amador ${ }^{5}$, and Ruddy Fallas-Zuñiga ${ }^{6}$ \\ ${ }^{1}$ Carrera de Ingeniería en Gestión Ambiental, Sede San Carlos, Universidad Técnica Nacional, Alajuela, Costa Rica (jorgepittasoma@gmail.com) \\ ${ }^{2}$ Técnico Medio en Turismo Ecológico, Colegio Técnico Profesional de la Fortuna, La Fortuna, Costa Rica (vic_sh94@live.com) \\ ${ }^{3}$ La Fortuna, San Carlos, Alajuela, Costa Rica (natugerald@gmail.com) \\ ${ }^{4}$ Frogs Heaven, Horquetas, Sarapiquí, Costa Rica (solisandrey21@gmail.com) \\ ${ }^{5}$ San Vito de Coto Brus, Puntarenas, Costa Rica (pipra14@yahoo.com) \\ ${ }^{6}$ La Lucha de Sabalito, Puntarenas, Costa Rica (fallasruddy@gmail.com)
}

Seven of the 27 species of glass frogs in the genus Hyalinobatrachium are found in Costa Rica (Leenders 2016). Male frogs of this genus usually call at night from the undersides of leaves in vegetation overhanging streams (Köhler 2011). The Yellow-striped Glass Frog (Hyalinobatrachium vireovittatum) is distinguished from other Costa Rican centrolenids by the presence of a green middorsal stripe bordered on both sides by yellow lines (Starrett and Savage 1973; Savage 2002; Kubicki 2007).

Principal habitat of Yellow-striped Glass Frogs is near wet walls, seepages, and small streams in mature primary and secondary forests (Kubicki 2007). The known distribution of the species in Costa Rica covers a narrow strip at eleva- tions between 250 and $1,100 \mathrm{~m}$ from the Carara National Park to Talamanca in the central and southern Pacific foothills (Savage 2002; Kubicki 2007), where only three sites (Alfombra and the foothills above Quepos in Costa Rica and El Valle in Panama) have been recorded (Kubicki 2007). Frogs identified as $H$. vireovittatum from the Tilarán Mountains in Costa Rica and el Copé in Panama actually are Talamanca Glass Frogs (H. talamancae) (Kubicki 2007).

On 5 September 2020, we encountered a previously unknown population of Hyalinobatrachium vireovittatum (Fig. 1) in the Canton of Coto Brus, Puntarenas Province, Costa Rica (8'56'30.8"N, 8243'39.0"W; WGS 84; elev. $1,957 \mathrm{~m}$ asl; Fig. 2), where several individuals were observed
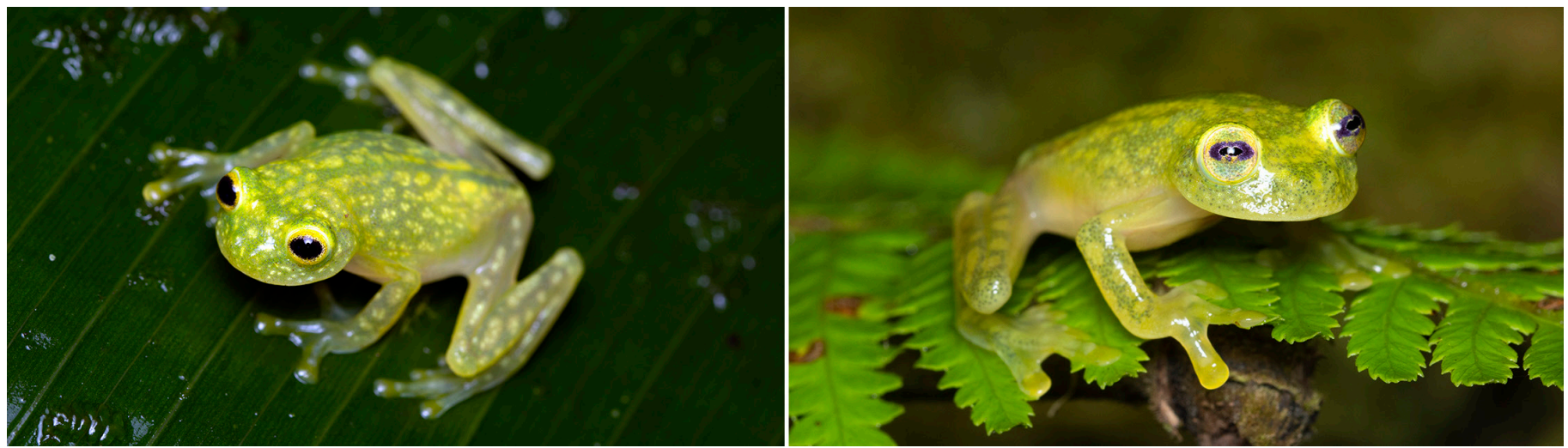

Fig.1. Yellow-striped Glass Frogs (Hyalinobatrachium vireovittatum) from the Las Tablas Protected Area, Coto Brus, Puntarenas, Costa Rica. Photographs by Henry Sandi (left) and Jorge Gabriel Campos(right). 


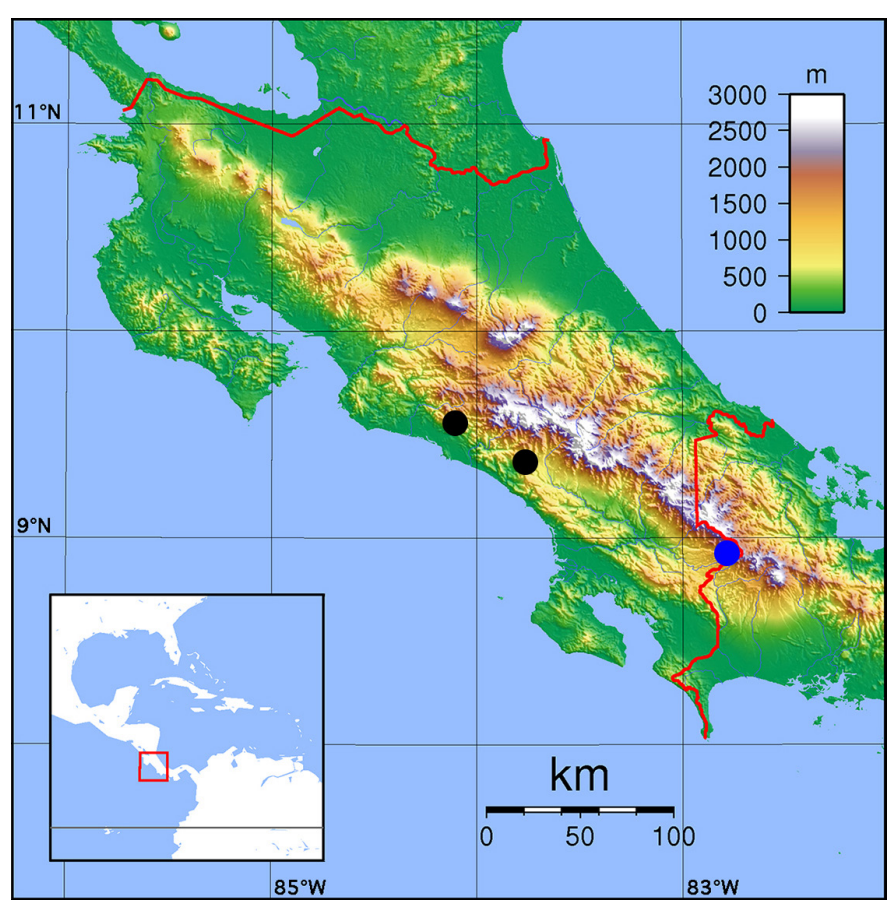

Fig. 2. Map of Costa Rica. Previously documented localities for Yellowstriped Glass Frogs (Hyalinobatrachium vireovittatum) are indicated by black dots. The new record reported herein is marked with a blue dot. and heard along the Coton River in the Las Tablas Protected Area. This new locality is $122 \mathrm{~km}$ straightline distance from the nearest previously known locality at Alfombra and extends the elevational range of the species by over $850 \mathrm{~m}$.

\section{Acknowledgement}

We thank the Fonseca Víquez family, owners of the Changuinolita Farm in the las Tablas area, who allowed us access to their property.

\section{Literature Cited}

Köhler G. 2011. Amphibians of Central America. Herpeton Verlag Elke Köhler, Offenbach, Germany.

Kubicki, B. 2007. Ranas de Vidrio Costa Rica/Glass Frogs of Costa Rica. Instituto Nacional de Biodiversidad (INBio), Santo Domingo de Heredia, Costa Rica.

Leenders, T. 2016. Amphibians of Costa Rica. A Field Guide. Zona Tropical Publications, Cornell University Press, Ithaca, New York.

Savage, J.M. 2002. The Amphibians and Reptiles of Costa Rica: A Herpetofauna Between Two Continents, Between Two Seas. University of Chicago Press, Chicago, Illinois.

Starrett, P.H. and J.M. Savage. 1973. The systematic status and distribution of Costa Rican glass-frogs, genus Centrolenella (Family Centrolenidae), with description of a new species. Bulletin of the Southern California Academy of Sciences 72: $57-78$. 